\title{
Redefining Personhood: A Synoptic Analysis of Human Subjectivity from Legal and Human Rights Perspective
}

\author{
MD Parvez Sattar \\ Department of Law, School of Liberal Arts and Social Sciences, Independent University Bangladesh (IUB), Dhaka, Bangladesh \\ Email: rana@iub.edu.bd,ranapsattar@gmail.com
}

How to cite this paper: Sattar, M. P. (2021). Redefining Personhood: A Synoptic Analysis of Human Subjectivity from Legal and Human Rights Perspective. Beijing Law Review, 12, 60-90.

https://doi.org/10.4236/blr.2021.121005

Received: January 9, 2021

Accepted: March 8, 2021

Published: March 11, 2021

Copyright (๑) 2021 by author(s) and Scientific Research Publishing Inc. This work is licensed under the Creative Commons Attribution International License (CC BY 4.0).

http://creativecommons.org/licenses/by/4.0/

\section{(c) (i) Open Access}

\begin{abstract}
Legal and political debates around defining the term person on the one hand, and personhood of human on the other, have in recent periods intensified in almost all legal sectors, from civil, criminal, corporate and public laws to emerging areas of human rights and humanitarian discourses. The purpose of this article is to delve into the increasingly significant conjunction between these two terminologies that has not been evidently clarified, either in the prevailing academic jargon or in the application of international normative standards. Accordingly, based on an inquisitive analysis, the paper emphasizes on the essence of humanistic approaches in redefining personhood from the perspectives of legal jurisprudence stemming from contemporary and emerging socio-political philosophy of international law. A key conclusion drawn relates to the fact that the proffered approach recognizes fundamental human rights as the foundational building blocks of the re-construed normative trends in inter- and intra-disciplinary reciprocation between personality and humanity.
\end{abstract}

\section{Keywords}

Personhood, Human and Person, Human, Person and Human Rights, Personhood in Humanistic Jurisprudence, Human Personality and Legal Humanism

\section{Introduction}

Historically, both in anthropological analysis in as much as in other cross disciplinary sociological studies and debates, the concept of personhood remained thematically complex and plausibly contradictory. The present article takes its point of departure from a jurisprudential spin-off in the contemporary devel- 
opment of international human rights law in defining personhood from a legal philosophical perspective. The underlying proposition of the paper is aimed at two closely indissociable conclusions. First, that the paradigm shift in the focuses on changes in legal culture, particularly in the post WWII era of global political "renovation" (Rose, 1998) has led to an innovative conjunction between law and development placing the human person in the center of the transition agenda. And second, the phenomena associated with the recognition of redefined personhood in the backdrop of universal humanity, ${ }^{1}$ a notional idiom in the new global order, re-emphasize a core basis of the "fourth generation" ${ }^{\text {" constructiv- }}$ ism, namely: the ultimate determinant of the attributing features of human is in being a human person itself. This revisited outlook is evident in the intrinsic parallelism underlying the first approach objectively in the broader but essentially inclusive values and visions of personhood in law, and subjectively in the inherent prerogative indelibly entrenched in the genesis of human rights based approaches (HRB) to the $21^{\text {st }}$ century reconceptualized personhood.

The two-fold propositional content of the paper is supported by illustrative arguments structured upon three major thematic premises: firstly, an analytic review of what is meant by "person" in ordinary socio-anthropological contexts as well as in legal usage vis-a-vi the etymological understanding and subjective application of the term "human" with specific reference to international human rights jurisprudence. The second proposition assesses the interactions, overlaps and contradictions between these two expressions referring to diverse philosophical approaches adopted for their metaphysical, phenomenological, historic and legal reasoning. These include reviewing the complex and puzzling terminological jumbles between the two: implications of person and humanhood in contemporary international law; the logic-realism wrangling embedded in the vicissitudes of age-old personhood debate; and the implications of personhood in global relations and international legal realm. It has been observed that there exists a large disagreement in relevant academic literature inasmuch as in normative application with regard to the meaning, definition and substance pertaining to these two expressions. Finally, the third perspective focuses on the increasingly expanding recognition and acceptance of humanistic lingo in the interpretation of personhood of human as against humanhood of person adopting human rights based approaches in contemporary jurisprudential thoughts.

\section{Terminological Muddles}

There have been conceptual and terminological traversing leading to frequent ${ }^{1}$ See, for instance, Paustian, M.C. (2019). A Postcolonial Theory of Universal Humanity: Bessie Head's Ethics of the Margins. Humanity Journal (January 15, 2019). Available at http://humanityjournal.org/issue9-3/a-postcolonial-theory-of-universal-humanity-bessie-heads-eth ics-of-the-margins/\#: :text=Abstract\%3A\%20Universal\%20humanity\%E2\%80\%94the\%20idea,guid ing\%20principle\%20of\%20humanitarian\%20action (accessed 28 December 2020).

${ }^{2}$ For the generational perception of human rights, see Weston B.H. (2014). The content of human rights: three "generations" of rights (Rev. 2014). Available at

https://www.britannica.com/topic/human-rights/Defining-human-rights\#ref219326 (accessed 18 February 2021). 
overlaps between the two terms: person and human. "Person" traditionally refers to "a being that consists of life and a soul, and possesses the capability of conscious thought, i.e. is a sentient being" (Broom, 2019). A human (scientific name-Homo sapiens), on the other hand, is the scientific term that used to describe a person. In that sense, from philosophical perspective, person is a term that describes a human being. In philosophy, human is seen as "human person as physical being, as knower, as responsible agent, as a person in relation to other persons, to society, to God, and to the end, or purpose, of human life" (Orebech et al., 2005).

The English adjective human is "a Middle English loanword borrowed from Old French humain", which originated in Latin hümānus, the adjective form of homo" "man" (Papazian, 2016). The Latin word homo refers to humans of either gender, and that "sapiens" is the singular form while there is actually no such word as "sapien". 3

Despite development of different theories and arguments that tend to establish certain analytical viewpoints in a philosophical commonplace, the inherent ambiguities and overlapping perception regarding the two terms still remain unresolved. While some scholars opined that although defining human is relatively straight forward, such as Aristotle's theory of "rationality" (Kietzmann, 2019), or the description suggested by the US National Museum of Natural History with regard to the essential traits of being a human (as a biological group known as primates), ${ }^{4}$ attempts made at reaching a consensus on the conceptual understanding and definition of a person entail complex issues and questions, and inevitably a never-ending debate.

Thus, viewed both from its legal and philosophical attributes, personhood has been approached and influenced heavily by historic and cultural transitions. Like the notions of "humanhood", personhood also combine and carry the theoretical and conjectural burdens of multifaceted visionaries: from Boethius's theory of "individual substance of a rational nature" (Koterski, 2004) to John Locke's "self-consciousness-based definition" (Boeker, 2013) or Emmanuel Kant's moral-philosophical definition of the person (Johnson \& Cureton, 2016), to the world of tomorrow that is naturally expected to explore avenues addressing new, complex issues and concerns that is likely to emerge pacing with the acceleration of technological advances.

Locke thought of a person as a "thinking intelligent being" (Locke, 2004) possessing the essential characteristic of consciousness, so much so that transferring a consciousness to another human body would result in the continuation of personal identity in another body. This meant that being a particular person was something quite different from being a particular human animal. However, the Lockean stance has been widely rejected by recent schools of thought advocating

${ }^{3}$ Online Etymology Dictionary. Homo sapiens (n.). Available at https://www.etymonline.com/word/homo\%20sapiens (last accessed 28 December 2020).

${ }^{4}$ National Museum of Natural History. What does it mean to be human? (October 27, 2020). Available at https://humanorigins.si.edu/evidence/behavior/primate-behavior (last accessed 01 Jan 2021). 
a view of personhood as a natural-kind term. Under this view, persons are simply biological organisms of sufficient complexity that we can attribute psychological as well as physical characteristics to them (Fieser, 2008). On the other hand, philosophers advocating a neo-Lockean position have strongly challenged this viewpoint by conducting a series of deeply controversial thought experiments meant to elicit Lockean intuitions (Ohlin, 2005). But the term "person" is so contested that it is not even clear whether the word is being used in the same way by each theorist. Locke provides a starting point in his suggestion that "person" is a forensic term, appropriating actions and their merit, and so belong only to intelligent agents capable of a law (Roth, 2019).

However, as emerged from the foregoing proposition, the term "person" refers to a being that has certain capacities or attributes that are defined differently by different scholars. The most common amongst these is that a person is someone who consists of life and a soul and has the capability of conscious thought. This is aptly illustrated by philosophers Michael Lacewing (Lacewing, 2017) and Thomas White (White, 2012) pointing out some basic criteria for persons. According to them a person should have a soul meaning that they should be alive and aware, should feel positive and negative sensations, have emotions, a sense of self, can control (govern) their behavior, recognize other persons living in the society and treat them appropriately, have languages or signs to communicate among themselves, and possess a variety of sophisticated cognitive abilities and rights. These approaches by Lacewing and Thomas are reflectively expressed by Charles Taylor (Taylor, 2012):

Where it is more than simply a synonym for "human being", "person" figures primarily in moral and legal discourse. A person is a being with a certain moral status, or a bearer of rights. But underlying the moral status, as its condition, are certain capacities. A person is a being who has a sense of self, has a notion of the future and the past, can hold values, make choices; in short, can adopt life-plans.

Again, the conceptual understanding of person is closely interlinked with the attributes of personality. Any living thing, which exhibits the characteristics of personality, might be taken as person. Question remains, could every individual demonstrating the common traits of humanity be similarly taken as a human person by default? This approach of questioning further accentuates the terminological muddles discussed above. In a linguistic levity, one may find the answer, albeit paradoxically, in the way the term is being used either as a noun or as an adjective. In the former instance, treating human (meaning people in general) as an "object" that essentially possesses "certain qualities" comes in sharp contrast with the latter (i.e. as an adjective) where there is no object but only "qualities". ${ }^{5}$ This confusion intensifies, even though representing a fact that is politically correct, when we proceed further to assert that even though an entity

${ }^{5}$ See, for instance, Alvarado, E. (2014). The Difference between a Person and a Human. Sonderbodhi (30 June 2014). Available at

https://medium.com/sonderbodhi/the-difference-between-a-person-and-a-human-6ccd219ffdb3.

Accessed on 14 February 2021. 
may not be a person in the sense of a noun, but may still be a human being used as an adjective. Similarly, another dimension of the phraseological back-and-forth, albeit in resemblance of the object-quality scramble, can be found in David A Hume's view that human persons are "nothing but a bundle of different perceptions", a proposition based on two contrasting approaches of "mentalistic" and "physicalistic" attributes (Riukas, 1998).

However, it may be noted that while all of these definitional jargons emanate from philosophical assertions on these two terminologies, the main concern of this paper is to critically review the contemporary debates on person and human, especially in reference to the modern-day human rights law. This aspect has been addressed in the following sections.

\section{Personhood in International Law}

\subsection{The 17th-19th Century Classical Phase of Subjective Positivism}

Public international laws (PIL) have revolved about states considered to be the sole subjects of international law. In the classical phase of the subjective positivism in the late $17^{\text {th }}$ and $18^{\text {th }}$ century, the individual was neither claimed to be subject nor object of international law, rather a "possessor of a status intermediate between these positions" (Manner, 1952). Grotius, in the $17^{\text {th }}$ century, in fact recognized the status of individuals as entities having rights and duties in the society of all mankind, while states were in his model still the primary actors (Cutler, 1991). However, notwithstanding these historical annotations, States were still at the forefront as subjects in international law by the end of the $19^{\text {th }}$ century and onwards, and it was only later that the individual was generally recognized as a subject.

It may, however, be noted that rights and duties as determinants of individual person's subjectivity in international law were asserted by scholars even in the $19^{\text {th }}$ century. Apart from the earlier theories of Hugo Grotius (Stumpf, 2012), Pufendorf (Phillipson, 1912) or Hobbes (Burelli, 2018), included amongst them are Heffter, Fiore, and Blantschli (Kohen \& Caflisch, 2007). Korowicz also refers to Heilborn, Martens and Wilhelm Kaufmann whose propositions can be interpreted to imply individual's personhood in international law in the protection of his human rights and freedoms (Korowicz, 1956).

\subsection{The $20^{\text {th }}$ Century Neo-Liberal Redefinition of International Subjectivity}

This part of the article focuses on the fact that, during the eventful courses of the $20^{\text {th }}$ Century, including two World Wars and the innovative progression of a renewed global governance framework (specifically by the introduction of the UN) picking up its acceleration in the second half of the Century in particular, individuals and other non-state entities become increasingly important actors under international law. This process, inextricably associated with recurring complex 
questions as to their legal standing in the international arena, eventually established that such entities by the contemporary neo-liberal redefinition of the terminology ("personhood" in PIL) started to (formally) enjoy both the status as objects and subjects.

Thus, to illustrate the proposition, on several occasions in the early $20^{\text {th }}$ century, courts came to the conclusion that it was within their jurisdiction to hear cases where individuals were involved (Spiermann, 2007). During the same period, right after the end of the First World War, the German-Polish Upper Silesian Convention, concluded in Geneva on May 15, 1922, an experimental initiative carried out on behalf of the Principal Allied Powers, is considered by many as one of the most interesting treaties from the point of view of the theory and practice of international law (e.g. Korowicz, 1956). This vast diplomatic instrument contained many new directions in the development of international law and was "full of surprising legal innovations" (Kaeckenbeeck \& Wood, 1943). Arguably, as noted by Hudson, this treaty represents the first formal international document that granted to individuals the right to stand before an international tribunal against not only a foreign government but also their own governments (Hudson, 1923).

Similarly, the creation of inter-governmental organizations, e.g. the International Labour Organization in 1919, with the broad objective of addressing the causes of labor and employment rights, was of great significance. The establishment of the Nuremberg Tribunal and the International Criminal Tribunals for Yugoslavia and Rwanda, added further to the development of international criminal law (Sattar, 2020b). As pointed out by Cassese, the Nuremberg definition of crimes against humanity marked a great advance (Dubler \& Kalyk, 2018), quoting the British Chief Prosecutor who spoke about the individual human person as "the ultimate unit of all law" (Kaczorowska, 2010).

\subsection{Emerging Questions of International Legal Personality}

The concept of personality is unequivocally linked to the subjects of international law. As noted by Dixon, personality is to be understood as "a body or entity recognized or accepted as being capable, of exercising international rights and duties" (Dixon, 2007). This means, that if an entity is said to have international legal personality, that entity is provided with rights and duties derived from international law, and this is argued in the following sections of the essay by providing evidence from international criminal law and international human rights law.

Significantly, the International Court of Justice, in the so-called Reparation for Injuries Opinion (1949), has linked the subjects of international law directly to the international legal personality and made it clear that there may be other subjects than states (Harris, 2004). As pointed out by McCorquodale: "while the State is the primary subject of the international legal system, the subjects of that system can change and expand depending on the needs of the [international] 
community and the requirements of international life" (Evans, 2018).

Rights and privileges that individual human person has been provided with under international law are of different character. They might be claim-rights, a privilege, a power, or immunity. The fact that individuals are provided with rights under international law, makes them subjects in their own right. The human rights sphere is incontestably the area in which individual rights under international law is most developed.

Talking about the requirements (conditio sine qua non) for recognition and activism of non-state subjects of international law within a given legal situation, Jan Klabbers considers personality of any such entity as "a threshold, which must be crossed" (Klabbers, 2010). In other words, claims and belonging to the global community of these entities are conditional to possessing legal personality in international law.

However, how the elements of this international legal personality are defined is an increasingly complex question that arises in the contemporary political and legal discourses, particularly in the context of recent development in international criminal justice and the principle of universality, application of international humanitarian law and individual responsibility for international crime as well as responsibilities for violation of norms and standards of international human rights law (Sattar, 2020b). Arguably, at least insofar as individual responsibility under the universality principle is concerned, the traditional requirement of legal personality in international law is no longer a condition precedent to entitlement to rights and duties in law-a proposition that comes in sharp contrast with the conventionalism (that existed even in the 1990s) ${ }^{6}$ affiliated to this long-maintained normative standing.

Naturally, what follows from the argument above is: does personality (or legal personality to be precise) in international legal discourse exclusively signifies possessing rights and obligations as in the case of the objects of PIL? In this respect, the point of view expressed by Kelsen can be interpreted to note that the law cannot just think in terms of rights and duties when it comes to the application of the law of nations, but also needs to be able to point to someone or something possessing those rights and duties arising from conventional as well as emerging attributes of subjectivity in international law (Kelsen \& Wedberg, 1945).

\subsection{Evolution of Transitional Theories and Their Interpretations}

In order to depict the transitional evolution in the understanding of personality from the perspectives of international law, reference may be made to some of the earlier theories propounded in this regard and their interpretations by subsequent advocates and proponents. A number of scholars, particularly in the 1940s and 50s, patronised a variety of earlier theories arguably largely influenced by the post-war global geo-political and institutional governance movements. At ${ }^{6}$ See, for instance, Amerasinghe, C.F. Principles of the Institutional Law of International Organizations (Cambridge University Press 1996), 69. 
least two of such theories are significant in our present context.

First, the classic idea of personality was translated by Von Savigny into a somewhat "modern" fictional idea postulating the legal person as an entity distinct from the natural person lacking any innate personality of its own as such. This thought was also supported by Figgis with reference to the "concession theory" (Figgis, 1995). On the other hand, however, a contending theory developed by Gierke and Maitland was the "realist theory" (Gierke \& Maitland, 1987). Under this theory, "an entity possesses a real existence, including its own will, distinct from that of other members. He would constitute, indeed, a real person".

The above stated position has been supported by Valerie Thomas in reference to the "legal status of nature" in contrast to "regulatory landscape attributing legal personality" at international and supra-national law from a three-fold rationale: 1) that at international law there is no recognition of the rights of nature per se, with international environmental protection mainly derived from an enforcement of human rights; 2) that there is a growing international Rights of Nature movement that recognizes that humankind and nature share a fundamental, non-anthropocentric relationship given our shared existence on this planet, and it creates guidance for actions that respect this relationship; and 3) that international law is useful in corralling states to action through soft norms such as reporting, diplomacy to encourage enforcement, etc. (Thomas, 2019).

\subsection{Modern International Law and Human-Centric Legality: A Paradigm Shift}

The modern notions of international law essentially started to develop after the Second World War because it was rightly conceived that international law needed a paradigm shift from the prevailing normative framework for regulating relations between sovereign entities to a body of law, corpus iuris, aimed at establishing peace, security and development. In fact, the essence of peace and security was a desperate call of civilization's survival following the devastating war. In a purely objective analysis, this peace was of essence not for the animals or for any other living being, but for human. Hence, the focal point of this whole innovation of law of peace, security and development was the well-being and recognition of human as human. And in every instance of normative and philosophical discourse, international law refers to "all human". It may thus be inferred that whenever there is a reference that "all humans are equal" for instance, it essentially means that only all "humans" are equal.

Again, the starting point of the development of modern international law was to establish human dignity and worth. As explicitly noted in the UN Charter (Article 1), the purpose of the new global organisation is to establish international peace and security and that no state shall use force against another state or interfere in the political integrity of another state. It was the first most authentic powerful international law because all the countries around the world had not only agreed to it but had also agreed to take collective action for a breach of this agreement. This global consensus was based on the primary doctrine of the law 
of nations-Pacta sunt servanda (i.e. agreement must be kept). And even though the global community at that time did not use the term human rights but used human dignity and worth, which ultimately meant the same.

Accordingly, the moment a human gives birth to a human, he is born with one thing, if nothing else, and that is his or her inherent fundamental human rights. This indeed implies a significant difference between a human and a person in human rights law. To understand this demarcating factor, it is necessary to understand what is meant by the term "person" from both legal (meaning systematic rules and guidelines) and jurisprudential (a theoretical study of law from different perspectives including legal philosophers and social scientists) points of view. This article only partially attempts to accommodate a discussion in that direction.

\subsection{The Transpiring Notions of Human and Personhood in International law}

A person in law is an entity who possesses rights, and hence, obligations by default. These rights could be ordinary legal rights, social rights, religious rights, moral rights and many more, but not necessarily human rights. With certain limitations defined by respective domestic laws, persons also have the capacity to sue and be sued and can enter into a contract. According to the Interpretation Act of 1978 in the UK, for instance, a person is a body either corporate or incorporate (Article 3). But what is essentially more relevant to note in the current context is that person is an entity with certain consistent pattern of characteristics or personality.

In the same line of argument, personality in international law refers to a combination of attributes and features possessed by an entity endowed with rights and obligations under public international law (PIL). Traditionally, as noted above, such entities in PIL were referred to as sovereign states, eventually (in later development) international organizations, multinational corporations, nongovernmental organizations, among others, were included as the subjects of PIL. In the modern development, starting particularly after the Second World War, individuals and certain groups such as insurgent and belligerent groups, national liberation movements, special case entities, protected territories, minorities and indigenous population and individual human persons have to a limited but in varied extent found places as subjects of PIL.

\section{Personhood: The Never Ending Debate}

From the flow of discussion in the above section focusing particularly on the perceptive evolution of personhood in international legal philosophy, an inevitable question addressed in the following section relates to the legal implications of the transitional interaction between person and human in academic debates as well their interpretations in conceptual jurisprudence. It has been demonstrated that even in the early stages of legal development that continued to embrace increasingly expanding issues and concerns, prevailing even in the present 
days, a reticent nexus always existed between individual's status and entitlement in legal, social and political strata, and the way personhood is perceived in a given jurisdiction.

Thus, for instance, Justinian's Roman law, in the $6^{\text {th }}$ century C.E., demonstrates the practice of treating certain individuals and groups as person, and hence entitled to specified rights and privileges. Such consequential entitlements to legal personality and rights entrenched from determining the status and levels of individual citizenry to ownership of property, placement in the socio-political power strata to notions of equality and liberty. Apart from these early practices in setting standards and norms for determining "human personality", the Middle Ages and the Renaissance witnessed legal and philosophical augmentation of the debate through attempts at establishing the "existential status" of "non-human personality" (LaGrandeur, 2014), treated by many as somewhat superstitious fairy-tale, such as the secrets of Alchemical Homunculus, which is a Latin for "little person" (Haynes, 2017) and Golem - an inanimate material brought to life by magic (Bilski, Idel, \& Ledig, 1988). However, as Dr. LaGrandeur aptly noted: "These sorts of historical stances on personhood are important because they elucidate the difficult social precedents facing any redefinition of non-human personhood today" (LaGrandeur, 2017).

However, legal and political debates around the question of personhood of human have intensified afresh with multifaceted dimensions and perspectives over the past few decades- particularly with the advent of the new international legal order in the second half of the twentieth century; the revived modern animal rights movements since the 1970s; the contemporaneous birth of the environmental movements; the ever expanding corporate veil doctrine of the late $19^{\text {th }}$ century $^{7}$ to the innovations of complex legal phenomena of transnational corporations throughout the $20^{\text {th }}$ and the current $21^{\text {st }}$ centuries.

Importance of addressing questions related to personhood gained momentum in almost all legal sectors from civil, criminal, corporate and public laws to emerging areas of human rights and humanitarian issues from abortion controversies to euthanasia, from gender debates to gay rights, from subjectivity and applicability of human rights standards to the increasing emphasis on the so-called "third generation" rights (environment, development, indigenous people, etc.). Recently, these apparently never-ending horizons of thematic and scholarly puzzles expanded further to even the most contemporary aspects of the political and regulatory challenges embedded in the increasing social, industrial and service sectors-ranging from healthcare, agriculture and manufacturing to education, mining and warfare-by artificial intelligence, android and humanoid robots (Alexandre, 2017).

\footnotetext{
${ }^{7}$ Salomon $v$ A Salomon \& Co Ltd [1896] UKHL 1.

${ }^{8}$ An expression adopted from Jensen, S.L.B. Putting to rest the Three Generations Theory of human rights (Nov 15, 2017). Available at https://www.openglobalrights.org/putting-to-rest-the-three-generations-theory-of-human-rights/\#: : :text=The\%20so\%2Dcalled\%20\%E2\%80\%9CThree\%20Generations,rights\%E2\%80\%94turns\%2040 \%20this\%20month (last accessed 28 December 2020).
} 
Thus, complex but engrossing legal questions were raised when, on October 25, 2017, robot Sophia was granted citizenship of Saudi Arabia (Walsh, 2017); or in November 2017, four "criminal" donkeys were "arrested" by police and later "jailed" by an Indian court in Uttar Pradesh for four days after being found guilty of destroying "very expensive plants" (Burns, 2017); or in March 2017, the Whanganui River in New Zealand became the first in the world to be granted the same legal rights as a person by a Bill passed by the New Zealand Parliament (BBC, 2017); or when, on July 4, 2018 in a unique ruling the Uttarakhand High Court in India accorded the status of a "legal person or entity" to animals in the state, saying "they have a distinct persona with corresponding rights, duties and liabilities of a living person" (Press Trust of India, 2018).

To state a few other instances in this regard: in 2015, the US Supreme Court granted petition to hear "legal persons" status in court (writ of habeas corpus) to two chimpanzees (Yuhas, 2015); in 2013, India’s Ministry of Environment and Forests prohibited capture of whales and dolphins and the establishment of dolphinaria in the country (Williamson, 2013); in 2007, Spain granted legal rights to great apes (Ortolani, 2018); in 2006, the UK Parliament accepted animals as sentient beings (Ares, 2019); in 2005, Austria became the first country to ban non-human ape experimentation (Project R\&R, 2005); in 2002, German parliament enacted a legislation extending constitutional rights to animals (Hooper, 2002); in 1999, New Zealand restricted experimental use of Great Apes (Fox, 2012); in 1992, Switzerland became the first country to constitutionally recognize animals as a "being" with a constitutional provision warranting the protection of "the dignity of the creature" (LE News, 2016).

The instances stated above are not of course exhaustive. What is placed at the center of the concern in each of the issues is the fact that the subjectivity requirement for legislative enactments or judicial proceedings call for the inevitable question of subjectiveness with regard to these regulatory interventionspersonhood to be precise.

It has been noted that the entity termed as person has been characterized from a variety of viewpoints. Arguably, most dominant among these typologies are the two mainstream categories of persons, i.e. natural and legal. Thus, for instance, in jurisprudential terms a "natural person" also called a physical person-obviously to mean individual human beings is one who has its own legal personality. On the other hand, a legal person is a person or entity entitled to do things that a natural person can legally do, such as enter into contracts, sue and be sued, own property (noted above).

Again, from the theological points of view, in religious or canon law, according to the Catholic Church, for instance, a person is a subject of certain legal rights and obligations (Vatican, 1983). The 1917 Code of Canon Law referred to all juridical persons as "moral persons", while the 1983 Code of Canon Law uses the term "moral person" solely to designate the Apostolic See and the Catholic Church itself (Coriden, Green, \& Heintschel, 1985). The Vatican pronounced in 1987 during the Congregation for the Doctrine of Faith that: "The human being 
is to be respected and treated as a person from the moment of conception; and therefore from that same moment his rights as a person must be recognized, among which in the first place is the inviolable right of every innocent human being to life" (Vatican, 1987).

In the Islamic legal and philosophical thoughts, a person is perceived to be a natural person, the greatest creation of God, who possesses attributes of morality, ethics, faith or Iman that denotes a Muslim's faith in the metaphysical aspects of Islam (Walbridge, 2017).

In Hinduism and Buddhism, it is significant to note that a sharp contradiction exits between these two religious outlook towards personhood-a concept that is meticulously dominated by factors related to mind, body and matters. This contradiction is marked by the acceptance of a core thought relating to the existence of the "self" (ätman) proclaiming that the self (ätman), cleansed from all the changes, variations and imbalances take place in the world of experience, a spiritual combination that is identical with the source and origin of all phenomena (brahman) (Dekeyser, 2017). "In Hinduism this thought has led to the divine goal of removing the bodily and empirical distractions from life, in order to understand the brahman nature within oneself" (Sivanada, 1997). By contrast, this perception of self or atman is rejected in Buddhism and an opposite trend of "non-self" or anatma is advocated for. As noted: "Contrary to Hindu philosophy, there is no eternal observer within a person, no "ghost in the machine" perceiving the physical world. The attman of the Upanishads rather is a momentary, selecting agent, shaped by its experiences and surroundings" (Dekeyser, 2017).

However, in the current context, two issues relating to their relevance in human rights law raise concerns: one, does the natural and legal person classification mean that norms and standards of human rights and freedoms are granted only to natural persons, and second, since all legal persons are not necessarily people (to mean human people), are they are entitled (or even able) to participate in all kinds of activities, rights and obligations as a natural person with legal personality? This remains academically debated and leads to several other related questions involving backward-forward linkages between natural and legal personality, such as the extent to which other identification of person, such as a non-human juristic or juridical person (for instance a business entity or a public or private agency), is entitled to enjoy rights and be subjected to duties at par with the other clusters of persons? These questions have been addressed in the following section focusing on the issue of relationship between personhood and human rights.

\section{Relation between Person, Human and Human Rights}

Human rights are rights inherent to all human beings and this is the very first philosophical core propounded by the pioneers of the postulant concept in the middle of the $20^{\text {th }}$ century that later continued to lay the foundation of the doc- 
trinal and normative development of international human rights law. A common parlance in almost all the major human rights treatise in defining the ideaand thereby portraying its subjectivity and entitlement- is expressed in the popular words: human rights are the basic rights and freedoms that belong to every person. At the centre of the idea lies the fact that these basic rights and freedoms represents a set of ideal standards that allow a person to live with dignity, freedom, equality, justice, and peace. Every "person" has these rights simply because they are human beings. On the other hand, as observed by the Stanford Encyclopedia of Philosophy (2019): "all living humans-or perhaps all living persons-have human rights". In both the approaches noted above, it is apparent that the terms person and human have been used synonymously in relation to human rights at least in the early development of the doctrine. The purpose of the following section of this article is to examine the scope and extent to which such subjective interchange between human, person and human rights reflect the post-modern conceptual innovations of personhood.

Ohlin (2005) opined that personhood is indispensable for making a human rights claim. Earlier, McCartney noted many different and conflicting notions in legal literature as to what constitutes "personhood", and attributing lack of consensus to our "age that eschews meta-physics and asserts that much of our understanding of reality is invented, created, or is the product of interpretation" (Mccartney, 2002).

It would be no exaggeration to say that the greatest innovation in the progressive development of a new world order in the twentieth century is the revolutionary global shift in revisiting the regulatory, institutional and politico-economic framework from the sovereign entity-the king and his prerogatives-to the wellbeing and interests of the individual human persons. As discussed earlier in this paper, along with the emphasis on maintenance of global peace and security based on international cooperation between nations, the pathway in the search for a new world led to a process founded essentially on recognition of dignity and worth of every human person as well as respect for and promotion of human rights and freedoms.

Accordingly, this process in its natural course established a profound connection between human and human rights. One may thus rightly argue that human rights themselves, transcending beyond their normative notions to a set of unique attributing features, define what humans are. In other words, it can be said that the beings that possess human rights are human.

Events in the trail of history remind us of the periods when despite possessing all other features and attributes, certain groups of individuals were not as such recognized as human (or fully human) such as the slaves, women or people of color (Jardina, 2019). Talking about placing human persons in differentiated hierarchical recognition (as human), in a comical gesture, one may recall George Orwell's Animal Farm-a text-based, choice-driven narrative where "all animals are equal, but some animals are more equal than others" (Britannica, 2020); or, 
on a more serious note, in the words of Thomas Jefferson, the $3^{\text {rd }}$ President of the US (1743-1826): “There's nothing more unequal than the equal treatment of unequal people" (Boyle \& Burns, 2012).

Furthermore, noted earlier in this section, it is obvious from the wording of the UDHR that the United Nations has clearly intended that "human rights" are rights inherent to all "humans". This would mean that an individual does not need to be a person to avail this right. But how can a human be a human and not a person? The 1857 case of Dred Scott $v$ John Sandford may aid in answering this question. It was decided in this case that a black man did not qualify as a citizen and hence not entitled to the rights and privileges. It was mooted in the court that he was indeed a "human being" but he did not qualify as a "person", that is a full member of the American society. Once again it is evident that person can be more than just a synonymous term of human and inevitably mean a member of a group as mentioned above.

In the above context, reference may also be made to another aspect of the long standing debate, i.e. the controversies involving humanhood of unborn child or fetus. Due to the specific relevance and significance of the status of fetus in terms of entitlement to basic human rights, this aspect is discussed in further details in this paper (see section VI below). It may, however, be noted at this stage that the American Convention on Human Rights (ACHR), 1969 is the only major human rights instrument that deviates from the common trend of the other international instruments by recognizing an unborn child as a human with entitlement to the right to life [Article 4(1)]. Also, the Convention in Article 1(2) states that that human means "every Person".

Along with the controversies around the question of personhood (and also humanhood) of fetuses, several theorists suggest that some animals meet most criteria for personhood and are therefore (arguably) claimants of certain human rights. Ohlin opines that "part of these debates stem from the law's reliance on the mutually exclusive concepts of persons and property", neither of which are entirely satisfactory for dealing with animals" (Ohlin, 2005). Again, from the perspective of social contact theory, in contrast to the utilitarian arguments in many animal rights literature (Francione, 1997), some animals have the "cognitive sophistication to be considered auxiliary members of the social contract and therefore deserve respect under the Kantian view" (Cavalieri, 2002). However, the questions involving as to how far these academic wrangles impact on the conceptual expansion of human rights and personhood are increasingly bringing experimental and inventive ideas (and hence controversies) in both national and international laws.

Another related issue that emerges from the reference to the term "everyone" (or "no one" in cases of right to freedom) in the international human rights instruments underlines resembling postulation of contrast and interconnectivity between the perceptive and jurisprudential rationalization of person and hu-

${ }^{9}[1857], 60$ U.S. 393. 
manhood. Thus, for instance, all the thirty articles enumerating the thirty substantive rights in the UDHR use the term "everyone" (or "no one"); the same may be observed with regard to the twelve substantive articles of the European Convention. It is not clear whether it was an intention of the drafters of the instruments to emphasize "natural person" as the subject of the rights protected by avoiding reference to "every person" in the relevant articles.

However, from the perspectives of the arguments justifying referral to "every individual" (and occasionally to "citizen" and "all people") in the African Charter on Human and Peoples' Rights, it appears evident that the Charter focuses its objectives within the framework of rights and freedoms of natural human person and groups thereof. Accordingly, from the postulated premises with regard to the terminological and typological implications in the preceding sections of this article, it is (arguably) logical to infer that a natural human person has been conceived to be the prima facie beneficiary of the rights and freedoms guaranteed by these instruments.

Again, the argument made above can be compared (and to some extent contrasted) with the use of the term "every person" in the American Convention of Human Rights, a contrast that can probably be explained by reference to Article 4(1) of the Convention that affirmatively indicates that the rights protected by the ACHR shall apply to every natural human person "from the moment of conception". This provision of the ACHR comes in sharp contrast with the "Due Process Clause" of the Fourteenth Amendment to the US Constitution providing that no states shall deprive any "person" of "life, liberty or property" without due process of law, a fundamental human right that is commonly recognized by all the major human rights instruments. However, it is not clear whether reference to "person" (or alternatively "everyone", "every individual" etc. as noted above) in these provisions of human rights instruments intended to mean that the person should only be a natural person, or would this also include legal and artificial persons (e.g. a corporation). ${ }^{10}$

In the Granger Cases (1877), ${ }^{11}$ the US Supreme Court in relation to the question of possessing and enjoying a property by incorporated entities clearly indicated that a corporation (a legal person) cannot be deprived of enjoying its property "without due process of Law". ${ }^{12}$ Although various decisions have held that the "liberty" guaranteed by the Fourteenth Amendment to the US Constitu-

\footnotetext{
10In the context of corporate personhood and the due process clauses under the U.S. Constitution, see Graham, H.J. (1938). The "Conspiracy Theory" of the Fourteenth Amendment. 47 Yale L.J. (1938) 371-403. Available at https://digitalcommons.law.yale.edu/ylj/vol47/iss3/3/ (last accessed 28 December 2020).

${ }^{11}$ The Granger Cases (1877): Munn v. Illinois, 94 U.S. 113; Chicago, Burlington \& Quincy Railroaa Co. v. Iowa, 94 U.S. 155; Peik v. Chicago \& Northwestern Railway Co., 94 U.S. 164; Chicago, Milwaukee \& St. Paul Railroad Co. v. Ackley, 94 U.S. 179; Winona and St. Peter Railroad Co. v. Blake, 94 U.S. 180; and Stone v. Wisconsin, 94 U.S. 181. See Encyclopedia.com (updated Feb 9, 2021). Granger Cases (1877). Available at https://www.encyclopedia.com/politics/encyclopedias-almanacs-transcripts-and-maps/granger-case s-1877 (accessed Feb 20, 2021).

${ }^{12}$ Munn v. Illinois 94 U.S. 113 (1877) and Gibbons v. Ogden 22 U.S. 9 Wheat. 11 (1824).
} 
tion is the liberty of natural, ${ }^{13}$ not artificial, persons, ${ }^{14}$ nevertheless, in 1936, a newspaper corporation successfully objected that a state law deprived it of liberty of the press. ${ }^{15}$

While the US constitution ascribes $14^{\text {th }}$ amendment rights to "persons", the UDHR makes reference to human beings and the International Covenant on Civil and Political Rights refers to both. Questions may arise as to the significance and/or implications, if any, of these terminological technicalities. There are also instances-such as the British Human Rights Act 1998 (HRA: Section 7) that enable any "person" to avail such right. One may notice that although the UK statute is titled as human rights, it specifically mentions that only a "person" can obtain that right. Apparently, a key indication of the HRA seems to be that it is not available for all humans, but rather individuals that fall within the categories of persons in regards to the UK's HRA, 1998.

However, from a different perspective, does the use of the term "person" mean that one has the same cognitive abilities that others from the same community do and that he belongs to a member of a social association? This would mean that the aliens in "E.T.", the extra-terrestrial character from George Lucas's 1977 science-fiction film Star Wars, that speak a language, make moral judgments, create their own habitat, etc. would also be considered "persons". Or, how about someone in a vegetative state, someone severely mentally handicapped? Such a person may still be a human in a natural course of thoughts, but may not be a person as he has lost or is unable to do what an ordinary person does-and hence perhaps be denounced of being a "person" in its technical sense.

Again, speaking generally, the rationale for animal rights activists to claim the status of a legal person for non-human animals is to protect them from abuse, brutality and unnecessary violence. It would probably not be inappropriate to use the term inhumane treatment in this regard. At the core of these activisms is the essential claim that animals are also entitled to certain rights and dignity (freedom from torture, for instance), like a Human person, or a human-animal to approach concomitantly, is inherently entitled to.

However, from the traditional legal mind-set, laws and courts are generally reluctant to give non-human animals the status of a legal person. An illustration of this may be seen in the New York State Supreme Court's case of Hercules \& Leo (2013) where a demand was made for recognition of Hercules" and Leo's (two chimpanzees) legal personhood and right to bodily liberty (through a writ of Habeas Corpus); the petition was finally rejected. ${ }^{16}$ It has been thus evident that legal and judicial frameworks consider animals as a thing rather than person. Arguably, the most liberal approach to animal personality is that even though animals can possess some characteristics of a person, but this should not

${ }^{13}$ Yick Wo v. Hopkins 118 U.S. 356 (1886); Terrace v. Thompson 263 U.S. 197, 216 (1923).

${ }^{14}$ Northwestern Life Ins. Co. v. Riggs 203 U.S. 243, 255 (1906).

${ }^{15}$ Grosjean v. American Press Co. 297 U.S. 233, 244 (1936).

${ }^{16}$ Hercules and Leo v. Stoney Brook (2015). Decision and Order. New York State Court. First District. July 29, 2015. Available at

https://law.justia.com/cases/new-york/other-courts/2015/2015-ny-slip-op-25257.html. 
be confounded with the legal person concept.

Again, it has been argued that a "person" has certain requirements that may not be met by animals. Thus, for instance, Bioethicist Joseph Fletcher (1972) presented a list of 15 positive propositions that define a person. These are: 1) Minimum intelligence; 2) Self-awareness; 3) Self-control; 4) A sense of time; 5) A sense of futurity; 6) A sense of the past; 7) The capacity to relate to others; 8) Concern for others; 9) Communication; 10) Control of existence; 11) Curiosity; 12) Change and changeability; 13) Balance of rationality and feeling; 14) Idiosyncrasy; and 15) Neo-cortical function. If an animal does not possess these 15 propositions then in accordance to Fletcher, they are not a person (Fletcher, 1972).

However, an inevitable question that arises in this regard is what if some animals do meet these criteria-the features of a sentiment being? What if an animal, such as an ape or dolphin, does have the minimum level of intelligence, self-awareness, self-control, a sense of time, curiosity and so on? It is believed by many modern scholars, Lori Marino amongst them, that such animals are indeed persons (Morell, 2014). This obviously has its limitations as not all animals share Marino's propositions, and therefore not all animals can be persons. However, this argument was further backed by prominent scientists when in 2012 they signed the Cambridge Declaration of Consciousness in which they clarified that they support the fact that animals are conscious and aware to the degree a "person" should be, similar to humans (Dvorsky, 2012). Therefore, one may state that since animals can possess characteristics of a person, they remain claimants of certain qualified personhood of their own both in legal and social philosophy as well as in ethological studies.

The flow of the preceding discussion also takes us to the question of personhood of incorporated entities. Human beings are natural persons while corporate entities cannot be human being, but can still be a legal person, also known as artificial person. Noted earlier, companies have been given the status of corporate personality as confirmed in the 1897 decision of Salomon v Salomon. ${ }^{17}$ However, what is relevant in the current context is to note that the concepts of human personality and the notions of corporate identity are essentially separate discourses. In the simplest terms, humanity is a state of nature and legal personality is an artificial construct-continuity and extent of which are conditional upon unique given circumstances.

Another much discussed but still emerging issue in legal jurisprudence is-what is the rationale behind allowing companies to claim status as a person when they are definitely not human? A common general principle of corporate rules of law practiced by national and international legal regimes is that a company is a separate legal entity from its members and accordingly possesses its own rights and obligations. This clerically means that a company has the ability to do something a person would be able to do. It is undoubtedly clear that a

${ }^{17}[1896]$ UKHL 1 . 
company could not be human as in order to belong to the human race one must be born from two homo sapiens, and be a homo sapiens himself or herself. A company, created by prescribed legal rules and procedures, does not meet these requirements, and hence cannot be treated as a human as such. However, while clearly companies cannot be a human person, in law, they are still recognized as a person in legal jurisprudence.

Comprehensively, the outcome from Salomon v. Salomon led to the lasting principle that a company has to fulfill its duties, has its rights, and is subject to certain obligations. Inevitably, as mentioned previously, a person is an identity, a being, that belongs to a group, has specified rights and bears certain obligations. More relevantly to the question, the rationale behind allowing companies to claim status as a person is to protect the whole concept of a company. If a company did not have its rights, did not have obligations or duties, and was not equivalent in the law to a person, then there would be no distinction between being a sole trader and running a company i.e. the doctrine of corporate veil (Green, 2010).

However, it was clarified in the Irish Supreme Court decision in Battle $v$ Irish Art Promotion Centre, ${ }^{18}$ that the company does indeed have its limitations and further in the UK case Re A Company, ${ }^{19}$ the courts clarified as to when the company, being a person can be stripped of its person-hood and how the veil can be pierced. Understandably, therefore, a legal person, a company, is a person and the rationale behind allowing a company to claim status as a person is to aid the way its businesses are done.

From the viewpoints highlighted above, taking this analysis to a broader perspective, this paper apparently deviates from a contemporary trend amongst academics and practitioners, while addressing the issue of person and humanhood in relation to human rights, of differentiating between civil rights and human rights. While liberty and human personality are seen as essentially integrated elements of being an individual person "possessing the human desire to achieve full potential and dignity" (McHugh, 1992), liberty and civil rights have been viewed as a qualified status with additional precondition of possessing certain standing in the legal strata, citizenship for example. In this sense, it has been noted that "human rights are rights one acquires by being alive. Civil rights are rights that one obtains by being a legal member of a certain political state" (Casey, Alayan, Jorgensen, \& Monroe, 2021).

However, in a parallel analysis, this article also finds itself content with one particular aspect of this debatable argument, i.e. the distinctions drawn in terms of application of constitutional or fundamental rights (also called civil rights in some jurisdictions, such as the USA) within a national jurisdiction, and that of the universal norms and standards of human rights.

Most national constitutions enumerate a catalogue of rights and freedoms as fundamental rights applicable to individual persons within the legal jurisdiction ${ }^{18}$ [1968] 1 IR 252.

${ }^{19}[1990]$ BCC 526 (No 001418 of 1988). 
of that country. Unlike the protection of international human rights, the fundamental or constitutional rights and freedoms are protected by the relevant laws of the land with judicial enforceability in the domestic courts concerned (even though many of these civil rights and freedoms overlap between human rights law and national laws). Since the attributes of citizenry as membership of a political state represent an agreement between specific individuals in question and the political entity, application of the fundamental rights dependently vary between the provisions in this regard in the domestic laws (Miller \& Cross, 2012). International law is not, generally speaking, responsible for overseeing enforcement of these latter rights within a domestic jurisdiction in contrast to the enforcement of human rights and liberties (Sattar, 2020a). Also, many national constitutions categorically specifies the fundamental rights that would apply only to the citizens and those that would apply to all citizens or not-within the legal jurisdiction of the state.

\section{Is Every Human A Person?}

What is clearly understood so far is the fact that person primarily includes human but all persons are not necessarily human. What spontaneously follows, in a reversing argument, is the question whether every human is a person. This question of difference between these two terminologies holds significant importance in contemporary legal development, particularly in the context of human rights law. As aptly remarked by James T. McHugh: "The difference between legal terms such as 'person' and 'human being' represents more than a question of standing or mere semantics" (McHugh, 1992).

Jens David Ohlin, while referring to some of the most contentious areas of human rights discourse to determine how the notion of the person is deployed, noted that "the concept of the person stands at the center of the legal controversy" (Ohlin, 2005). Ohlin mentions numerous clustered groups of personality in this discourse such as partial persons (children), potential persons (fetuses and embryos), past persons (brain-dead patients), almost persons (animals), irrational persons (patients with multiple personality disorder), and group persons (corporations and nation states).

As we have seen in the discussion above, due particularly to the multidimensional conveyance of its varied usage (natural, legal, artificial, juridical), the word person is more dominant than human in legal vocabulary as well as the normative world of human rights treatises. A human without being a person cannot possess any right, or enjoy any privileges, under any law. This depicts that notwithstanding being a Homo Sapiens, not all human can be a person as well. If every human could be a person, then even a brain-dead patient or a disable human would have been regarded as a person under law with entitlement to all legal rights and privileges. For example, in order to qualify to become a party to a contract, from legal perspectives, a human becomes a person after attaining certain pre-conditions, for instance, they need to be sui juris (i.e. must have at- 
tained the age of majority), should possess a sound mind, or not otherwise disqualified from entering into a legal contract by any law to which he is subject (alien enemy, foreign sovereigns and diplomats, convicts, insolvents, etc.). ${ }^{20}$

By contrast, however, it also cannot be asserted that every person under law is necessarily a human. For instance, incorporated entities are legal persons but not human. In a similar trend of analysis it can also be said that not all human can be a person under the law. However, in the light of the arguments in this paper, it may be asserted that with regard to human rights provisions related to the specification of person does not play a vital role. It is a clearly established fact that any human recognized by medical science as a human person could be eligible to enjoy the protection and benefits of fundamental human rights and freedoms.

Frederick J. White referred to the social order that recognizes personhood of human in the context of two competing constructs-"an existential construct that personhood is a state of being inherent and essential to the human species, and a relational construct that personhood is a conditional state of value defined by society" (White, 2013). These two-fold constructs apparently represents a contraflow argument between empiricism and rationalism in the analysis of personhood. He places particular emphasis on the superiority of the existential construct in the interpersonal context depicting personhood as "an essential characteristic of the human species and is not a conditional state dependent upon circumstance, perception, cognition, or societal dictum" (White, 2013).

Conservatively, the above stated approach of existential versus relational constructs of personhood is clustered around an earlier classification proposed by John P. Lizza who grouped the ideas into eight categories: "persons as immaterial souls, persons as ensouled bodies, persons as human organisms, persons as psychological qualities or functions, persons as psychological substances, persons as constituted by bodies, persons as relational beings, and persons as self-conscious beings" (Lizza, 2009). Much earlier, in the $17^{\text {th }}$ century philosophy, the epistemological view of "rationalism" (that there are two kinds of beings or "substances") propounded by René Descartes famously conceived of persons as the union of body and soul, and fundamentally, the union of two kinds of substance, res extensa (the physical element) and res cogitans (mental elements) (Howard, 2003). White's $21^{\text {st }}$ century thoughts on the existential construct of personhood thus further expands upon the substance "dualism" of personhood combining mind and body.

In the above regard, however, the underlying proposition of this paper takes a neutral stance, if not opposing, concurring partly with White's interpersonal contexts to the extent that personhood is independent of the status of the human being. However, insofar as prevailing philosophy and norms of international law are concerned, this article is not fully aligned with White's idea of "human rights and the genesis of society and law" as the inalienable characteristic of person-

\footnotetext{
${ }^{20}$ Konappa Rudrappa Nadgouda vs Vishwanath Reddy \& Anr [1969] AIR 447.
} 
hood; that there is no essential association between personhood and rights; or that personhood is inviolable.

This is evident from the foregoing arguments that while every human essentially possesses the claims, rights and titles of a person (with defined limitations and conditions in exceptional circumstances), the debated designation of person does not necessarily connect to humanhood. There are persons in law, discussed earlier, who are treated as persons for limited legal purposes. On the other hand, a human in certain circumstances and conditions, may not possess the same attributes of a legal person.

Generally speaking, a minor, a person of unsound mind or an alien enemy, for instance, cannot enter in to a contract or be a party to judicial proceedings but they still remain human. By contrast, a human person, convicted of a crime, can be deprived of his right to life, personal freedom and many other claims, titles and social belonging. A non-human legal entity may lose its personhood by lapse of its incorporation. Also, like humanhood, the attributes of person are not inherent, inalienable or universal; legal personhood is acquired (and expires) by the operation of law. What we conclude from the discussion above is that while loss of certain legal personhood does not by default remove humanhood from a human person, there is no vice versa.

Now, in the context of our analysis of the question: "is every human a person"-we revert to the issue of humanhood of an unborn child or fetus. In fact, the issue of whether an unborn child (foetus) can be treated as a person, or human has been a subject of controversy for a long period-both in social philosophy inasmuch as in legal debates. As noted earlier in this paper, although body corporates may possess personhood and hence certain human rights, international human rights law is still stringent to entitle foetuses with such rights. Nevertheless, there are rights such as foetal rights for foetuses which are the moral rights or legal rights of the human foetus under natural and civil law (Gallagher, 1987).

Foetal rights came into wide usage after the much talked about landmark US case of Roe $v$ Wade ${ }^{21}$ that legalized abortion in the United States in 1973. At the international plane, as noted earlier, the American Convention on Human Rights is the only international treaty that specifically deals with foetal rights. The construction of Article 4(1) of the ACHR is notably distinct. It says that the right to life of every "person" is protected "in general, from the moment of conception". However, what is also significant to note is the fact that the use of the phrase "in general" in Article 4(1) of the Convention indicates that the right to life is not absolute from the moment of conception (Erdman \& Cook, 2005). Other regional and international instruments are silent as to any temporal limitations on the right to life.

In Vo $v$ France, ${ }^{22}$ the European Court of Human Rights made it clear that they did not desire the interpretation nor had the resources to answer in the abstract

\footnotetext{
${ }^{21}$ [1973] 410 U.S. 113.

${ }^{22}$ Application No. 53924/00; [2005] 40 EHRR 12.
} 
the question whether the unborn child is a person for the purposes of Article 2 of the Convention (right to life). Evidently, although attempts have been made to include the foetus in the constitutions and civil codes of several countries as legal person entitled to specified rights, many believe that this issue needs more time and efforts in order to settle its legal and other socio-cultural and religious controversies (Romanis, 2019). Erdman focuses on three struggles over time in abortion and human rights law: those related to morality, health, and justice (Erdman, 2017).

Nevertheless, in the current legal contexts-domestic and international-it may be argued that foetuses do not fall under the definition of humans since they do not possess human rights. However, to determine whether or not they are regarded as persons, the recent UK case $A B C{ }_{V}$ St George's Healthcare NHS Trust ${ }^{3}$ made an observation advancing a step further in attributing a legal identity to foetuses. In this case, the doctors had conducted a caesarean operation even though the mother had not consented to it. Hence, upon bringing a claim against the doctors, the UK High Court held that the mother was entitled to make her own decision since the foetus was neither a human nor a person. This decision was reached following the born-alive principle (Sattar, Khan, \& Reza, 2021). Even though the case of Commonwealth ${ }_{V}$ Cass $^{24}$ indicates that USA clearly denies this principle, the St. George's case makes it evident that UK jurisdiction is very affirmative about this principle. Looking back to the historical development of foetal laws in UK, the basic precinct of regarding foetuses as not-yet-human "has been shaped from the perspective of criminal law governing abortion and (to a lesser extent) the civil law of torts relating to pre-birth injury. Through advancing technology, the foetus is increasingly 'taking on a human form' in utero before our eyes" (Morris, 1997).

However, the UK and US cases stated above can be further collaborated by the Canadian case of Tremblay $v$ Daigle, ${ }^{25}$ where the court of appeal opined that since the Quebec Charter of Human Rights and Freedoms 1975 guaranteed the right to life of every human being and not that of a person, the 21-week old foetus in this case also had the right to life. Nonetheless, this is in relation to Canadian law disagreed in the UK jurisdiction where the foetus is not a person even for an offence under the Offence Against the Person Act 1861. This position was clearly confirmed in the case of $R_{V}$ Bourn $e^{26}$ and several later decisions. ${ }^{27}$

The conception of the beginning of human life in terms of juridical implications had two sets of judgments of relevance. The first one, dealing with the nature and juridical condition of a human foetus is a judgment of the European Court of Human Rights, in the case of Vo v France. The second one deals with human embryos and is represented by judgments of the European Court in the ${ }^{23}$ [2020] EWHC 455 (QB).

${ }^{24}$ [1984] 392 Mass 799, 467 N.E.2d 1324.

${ }^{25}$ [1989] 2 S.C.R. 530.

${ }^{26}$ [1938] 3 All ER 615

${ }^{27}$ For instance, Paton v British Pregnancy Advisory Service Trustees [1979] QB276; K v. Minister of Youth and Community Services (1982) 1 N.S.W.L.R. 311. 
case of Evans $v$ United Kingdom (see below).

In fact, the European Court of Human Rights previously opined in the same line with different words considering that the issue of when the right to life begins is a question to be decided at national level. It also established that at European level, there is no consensus on the nature and status of the embryo and/or foetus. At best, it can be regarded as common ground between States that "embryo/foetus belonged to the human race, its potential and capacity to become a person requires protection in the name of human dignity, without making it a person with the right to life for the purpose of Article 2" (José, 2013). The same conclusion was reached in the case Evans $v$ United Kingdom ${ }^{28}$ where the European Court of Human Rights eventually refused to recognize eventually the right to life under Article 2 of the European Convention of Human Rights to human embryos.

\section{Human and Legal Personhood in Human Rights Framework}

Noted in the earlier section of this paper, although "humans" and "persons" are terms that are often used interchangeably in the international human rights vocabulary, none of the international human rights instruments, global or regional, attempts to define the words in jurisprudential terms with the only exception of the American Convention on Human Rights, 1969 (ACHR). The Inter-American Court of Human Rights (IACtHR) in a 2016 Advisory Opinion examined the question of whether legal entities have standing before the Human Rights Court and finds that "a literal interpretation of Article 1.2 of the Convention leaves no space for doubt, since it states that 'person' means human being". ${ }^{29}$ In this regard, as noted by Florencia Bohl, "the eventual conclusion of legal entities lacking a stand before the human rights system (because they are not human rights holders) leads to a closure of the potential justiciability of legal entities' human rights" (Bohl, 2016). In that sense, it affects the right to an effective remedy for both natural and legal persons. It is further noted that the IACtHR addressed the issues surrounding the interpretation of Article 1.2 of the American Convention of Human Rights (ACHR) in a "literal, teleological, systemic, and evolutionary approach" (Bohl, 2016).

In our natural reflex of thoughts we take it for granted as obvious fact that human is a certain personality that exists as a human in this world. We do not recognize the necessity of determining who will be human and who will not be. With the changing world where we have artificial intelligence taking priority and dominance in our social, business or industrial lives, and in a world where green rights, animal rights, developmental rights and so forth are requiring more legal protections to be ensured, the question of legal personality for non-human entities are getting increasing eminence.

${ }^{28}$ Evans v. United Kingdom [GC] App. No. 6339/05, 46 Eur. H.R. Rep. 34 (2008).

${ }^{29}$ The Inter-American Court of Human Rights, Advisory Opinion OC-22/16 of February 26, 2016. Series A No. 22. 
This paper has asserted that (arguably) humans are human because they have human rights (at least in the modern usage of the term). The underlying concepts of the idea that humans inherently and in natural course of life have what has been termed as human rights in the middle of the twentieth century is deeply rooted in the British legal history because of the landmark developments in that jurisdiction in civil rights movements such as the Magna Carta of 1215, the Habeas Corpus Act of 1679 and the Bill of Rights (1689). All of these historic documents helped building the inner frame of the modern human rights law. However, question still remains what do these events and documents mean when they use the terminology human?

For understandable reasons, human rights law does not define the term "human" as such because back in 1948 or 1950, during the drafting and adoption of the Universal Declaration of Human Rights (UDHR) or the European Convention of Human Rights (ECHR), among other instruments, the drafters did not feel the need to define this term. However, one may still argue that human rights law does not require a discussion on who is a human as human have become human because they have human rights. From this perspective, none of the definitions of the term human can be treated as conclusive.

Accordingly, it may rightly be argued that humanity needs to have a definition that justifies humanity in its legal perception because human rights cannot describe human. From the perspectives of this article, the term "human" did not attain its full acknowledgement as a normative terminology until the revolutionary development of the international legal edifice (as a complex system of beliefs) of human rights- a set of universal common standards to define and establish the inherent dignity and worth that formally institutionalized the human species as the indubitable and unassailable claimant of fundamental rights and freedoms. Prior to this, humans were humans in a sense of a scientific expression or as the subject centripetal to the cores of social philosophy or demographic phenomenon, not an existence that resembles certain qualities and characteristics in the concrete terms of international human rights law that differentiate humans from other living animals.

Considering the above argument from a different perspective, apart from the theological disagreements in this regard, looking back to the propositions made in relation to the constituting traits-the characteristic features and distinguishing attributes of human-it is puzzling to perceive in the context of the traditional approaches to humanhood that humans in the historic timelines of evolutionary anthropology were "less human" every previous day, at least travelling backward by six million years to the world of Hominidae-the chimpanzees, gorillas, and orangutans (Pontzer, 2012). This academic puzzle is irrespective of the consideration whether humans in this biological theory of evolution attain more humanity tomorrow compared to today. As noted in this paper, the terminological tangle created by reference to person, human, everyone, etc., "without indicating whether each term encapsulates distinct or overlapping groups" (Ohlin, 2005), 
leads to complex legal controversies with regard to what may be called as qualified persons such as partial, potential, past or almost persons.

Again, theories propounded by the naturalists, Darwinism and other, the "Adam-Eve" concept of the origin of human creation in theology, Thomas Hobbes" "social contract theory" (human as "unsocial" being-individualistic, competitive, envious, hateful and belligerent) (Lloyd \& Sreedhar, 2002) and its sharp contradiction by Emmanuel Kant's refusal of the negativity of human person by recognizing "the dignity of humanity in every other man" based on morality and rationality (Von der Pfordten, 2009), or the possessor of rights, protections, privileges, responsibilities and liberty in the modern day politico-legal frameworks, have been accosted with emerging jurisprudential concerns in the recent and contemporary development in human rights based approaches to personhood.

\section{Conclusion}

Even in the twenty-first century post-modernity, as revealed in the increasingly expanding globalization of socio-economic and technological revolutions, the age-old debate of "personhood" has not fully come to a compromise, let alone be resolved. In the most popular trends of this discourse around the world, from legal jurisprudence to socio-political philosophy, the focus has only shifted, albeit in more complex and broader spectrum, from the ancient anthropocentric approaches ${ }^{30}$ to the evolving notions of biocentrism or sentiocentrism (Bekoff \& Meaney, 2013), ecocentrism (Newman, 2011), technocentrism (Mason, 2012), corporate-centrism (Sirota, 2004), and so on.

Based on a synoptic analysis of the propositions made in this article, it is now clearly evident that the correlated concept of human and person is embedded in a broad area of legal and philosophical concerns that have been addressed with different strategies, visions and approaches. In so far as international human rights law is concerned, the thematic differences between the two terminologies, or the application thereof in international normative standards, have not been clarified.

Again, the underlying proposition of the paper also indicates that personhood holds an imperative position in daily real life as well as in legal jurisprudence. It is undeniable that only being a biological human being is not enough to live a life with the basic standards of dignity, worth and social standing; the status and recognition of personhood in law is equally, if not more, more important to possess in this regard. These also lead the analysis to the future of the concept of personhood, and to some extent human as well, as it is apparently inevitable that in the rapid progression of science and technology, among other factors, there

\footnotetext{
${ }^{30}$ For a general discussion on the anthropocentric approaches that views humans as the most important thing in the universe, see Encyclopedia.com (2019). Anthropocentrism. (Updated Feb 26, 2020). Available at

https://www.encyclopedia.com/history/modern-europe/czech-and-slovak-history/anthropocentris m (last accessed 28 December 2020).
} 
are several other potential categories of beings and existence where personhood is, and would increasingly be, a supervening concern. While some would justifiably argue that many of these issues are founded on merely predicted whats and ifs, from a realist's perspective, academically, today's world needs to recognize the essence of redefining the concept of personhood in conjunction with the contemporary notions of humanhood.

Accordingly, this paper concludes its intended proposition with an emphasis on the essence of these HRB approaches in redefining personhood premised on the core doctrinal discourse in international law that unequivocally recognizes the broadening spectrum of dignity, rights and freedom as the foundational building blocks of the re-construed ideas and standards in inter and intra-disciplinary reciprocation between personality and humanity.

\section{Conflicts of Interest}

The author declares no conflicts of interest regarding the publication of this paper.

\section{References}

Alexandre, F. M. (2017). The Legal Status of Artificially Intelligent Robots: Personhood, Taxation and Control. SSRN Electronic Journal. https://doi.org/10.2139/ssrn.2985466

Ares, E. (2019). Animal Sentience and Brexit. UK Parliament, House of Commons Library. https://commonslibrary.parliament.uk/research-briefings/cbp-8155/

BBC (2017). New Zealand River First in the World to Be Given Legal Human Status. BBC News. https://www.bbc.com/news/world-asia-39282918

Bekoff, M., \& Meaney, C. A. (2013). Encyclopedia of Animal Rights and Animal Welfare (p. 159). New York: Routledge. https://doi.org/10.4324/9781315062075

Bilski, E., Idel, M., \& Ledig, E. (1988). Golem!: Danger, Deliverance and Art (p. 44). New York: Jewish Museum.

Boeker, R. (2013). John Locke on Persons and Personal Identity. St Andrews Research Repository. https://research-repository.st-andrews.ac.uk/handle/10023/3609

Bohl, F. (2016). A Commentary on Recent Developments in the Inter-American Court of Human Rights" Advisory Opinion on the Standing of Legal Entities. Oxford Human Rights Hub.

https://ohrh.law.ox.ac.uk/a-commentary-on-recent-developments-in-the-inter-america n-court-of-human-rights-advisory-opinion-on-the-standing-of-legal-entities/

Boyle, P., \& Burns, D. (2012). Preserving the Public in Public Schools: Visions, Values, Conflicts, and Choices (p. 131). Lanham, MD: R\&L Education.

Britannica, The Editors of Encyclopaedia (2020). Animal Farm. Encyclopedia Britannica, 27 March 2020. https://www.britannica.com/topic/Animal-Farm

Broom, D. M. (2019). Sentience. In J. C. Choe (Ed.), Encyclopedia of Animal Behavior (pp. 131-133). Cambridge, MA: Academic Press. https://doi.org/10.1016/B978-0-12-809633-8.90147-X

Burelli, C. (2018). Subjectivity Is Objective. Thomas Hobbes on Normative Truth. Notizie di Politeia, 34, 98-113.

https://www.researchgate.net/publication/325286612_Subjectivity_is_objective_Thoma s_hobbes_on_normative_truth 
Burns, I. (2017). Donkey Con: Eight Donkeys Are Jailed for Four Days for Destroying Plants outside a Prison in India. Daily Mail.

https://www.dailymail.co.uk/news/article-5124365/Eight-donkeys-jailed-four-days-Ind ia.html

Casey, H., Alayan, K., Jorgensen, R., \& Monroe, B. (2021). Civil Rights versus Human Rights. In A Brief History of Civil Rights in the United States. Georgetown Law Library.

https://guides.ll.georgetown.edu/civilrights\#: :text=What\%20is\%20the\%20difference\% 20between,of\%20a\%20certain\%20political\%20state

Cavalieri, P. (2002). The Animal Question: Why Nonhuman Animals Deserve Human Rights. Oxford: Oxford University Press.

Coriden, J. A., Green, T. J., \& Heintschel, D. E. (1985). The Code of Canon Law: A Text and Commentary (p. 80). New York: Paulist Press.

Cutler, A. C. (1991). The "Grotian Tradition" in International Relations. Review of International Studies, 17, 41-65. https://www.jstor.org/stable/20097243?seq=1 https://doi.org/10.1017/S0260210500112318

Dekeyser, J. (2017). A Different Conception of Personhood in Hinduism and Buddhism. Eternal India.

https://eternalbharat.wordpress.com/2017/01/07/a-different-conception-of-personhoo d-in-hinduism-and-buddhism/

Dixon, M. (2007). Textbook on International Law (p. 112). Oxford: Oxford University Press.

Dubler, R., \& Kalyk, M. (2018). The Nuremberg Precedent. In R. Dubler, \& M. Kalyk (Eds.), Crimes against Humanity in the 21 st Century (pp. 35-99). Leiden: Brill Nijhoff. https://doi.org/10.1163/9789004347687_003

Dvorsky, G. (2012). Prominent Scientists Sign Declaration That Animals Have Conscious Awareness, Just Like Us. Gizmodo.

https://io9.gizmodo.com/prominent-scientists-sign-declaration-that-animals-have-593 $\underline{7356}$

Erdman, J. N. (2017). Theorizing Time in Abortion Law and Human Rights. Health and Human Rights, 19, 29-40.

https://www.researchgate.net/publication/317703907_Theorizing_Time_in_Abortion Law_and_Human_Rights

Erdman, J., \& Cook, R. J. (2005). The Interpretation of Article 4(1) of the American Convention on Human Rights Consistently with the Human Rights of Women. International Programme on Reproductive and Sexual Health Law, University of Toronto. https://www.law.utoronto.ca/documents/reprohealth/BriefColombiaEng2005.pdf

Evans, M. (Ed.) (2018). International Law (p. 287). Oxford: Oxford University Press. https://doi.org/10.1093/he/9780198791836.001.0001

Fieser, J. (2008). Chapter 3: Mind. In Great Issues in Philosophy. https://www.utm.edu/staff/jfieser/class/120/3-mind.htm

Figgis, J. N. (1995). Respublica Christiana. In J. Stapleton (Ed.), Group Rights: Perspectives Since 1900 (pp. 38-60). South Bend, IN: St. Augustine’s Press.

Fletcher, J. (1972). Indicators of Humanhood: A Tentative Profile of Man. The Hastings Center Report, 2, 1-4. https://doi.org/10.2307/3561570

Fox, J. (2012). Great Ape Personhood. Law School Student Scholarship, 102. https://scholarship.shu.edu/student_scholarship/102/

Francione, G. L. (1997). Animal Rights Theory and Utilitarianism: Relative Normative 
Guidance. Animal Law, 3, 75-102.

https://www.animallaw.info/article/animal-rights-theory-and-utilitarianism-relative-n ormative-guidance

Gallagher, J. (1987). Prenatal Invasions \& Interventions: What's Wrong with Fetal Rights. Harvard Women's Law Journal, 10, 9-58.

https://heinonline.org/HOL/LandingPage?handle=hein.journals/hwlj10\&div=6\&id=\&p age

Gierke, O., \& Maitland, F. W. (1987). Political Theories of the Middle Age (pp. 67-73). Cambridge: Cambridge University Press.

Green, R. (2010). Companies vs Sole Traders: Things You Need to Consider. Toronto: Thomson Reuters.

https://www.cleardocs.com/clearlaw/business-structuring/companies-vs-sole-traders.ht $\underline{\mathrm{ml}}$

Harris, D. J. (2004). Cases and Materials on International Law (pp. 131-132). London: Sweet \& Maxwell.

Haynes, R. D. (2017). From Madman to Crime Fighter: The Scientist in Western Culture (p. 17). Baltimore, MD: JHU Press.

Hooper, J. (2002). German Parliament Votes to Give Animals Constitutional Rights. The Guardian. https://www.theguardian.com/world/2002/may/18/animalwelfare.uk

Howard, R. (2003). Dualism. In E. N. Zalta (Ed.), The Stanford Encyclopedia of Philosophy. https://plato.stanford.edu/entries/dualism/

Hudson, M. O. (1923). The Permanent Court of International Justice-An Indispensable First Step. The Annals of the American Academy of Political and Social Science, 108, 188-192. https://doi.org/10.1177/000271622310800135

Jardina, A. (2019). The Dehumanization of Blacks \& White Support for Punitive Criminal Justice Policy. American Politics and Public Policy Workshop, Institution for Social and Policy Studies. Yale ISPS.

https://isps.yale.edu/events/2019/09/the-dehumanization-of-blacks-white-support-forpunitive-criminal-justice-policy

Johnson, R., \& Cureton, A. (2016). Kant's Moral Philosophy. In Stanford Encyclopedia of Philosophy. https://plato.stanford.edu/entries/kant-moral/

José, D. G. S. (2013). The Juridical Conceptualization of the Human Embryo in the Law of the European Union. A Well-Aimed Step in the Wrong Direction. Anuario Mexicano de Derecho Internacional, 13, 517-548. https://doi.org/10.1016/S1870-4654(13)71049-3

Kaczorowska, A. (2010). Public International Law (p. 212). London: Routledge. https://doi.org/10.4324/9780203848470

Kaeckenbeeck, G., \& Wood, H. M. (1943). The International Experiment of Upper Silesia. International Affairs Review Supplement, 19, 623-624. https://doi.org/10.2307/3026005

Kelsen, H., \& Wedberg, A. (1945). General Theory of Law and State (p. 93). Russell \& Russell.

Kietzmann, C. (2019). Aristotle on the Definition of What It Is to Be Human. In G. Keil, \& N. Kreft (Eds.), Aristotle's Anthropology (pp. 25-43). Cambridge: Cambridge University Press. https://doi.org/10.1017/9781108131643.002

Klabbers, J. (2010). The Concept of Legal Personality. In F. Johns (Ed.), International Legal Personality (pp. 3-34). Abingdon-on-Thames: Routledge. https://doi.org/10.4324/9781315092485-2

Kohen, M. G., \& Caflisch, L. (2007). Promoting Justice, Human Rights and Conflict Res- 
olution through International Law/La promotion de la justice, des droits de l'homme et du règlement des conflits par le droit international (p. 449). Leiden: Martinus Nijhoff Publishers. https://doi.org/10.1163/ej.9789004153837.i-1236

Korowicz, M. (1956). The Problem of the International Personality of Individuals. The American Journal of International Law, 50, 533-562.

https://www.jstor.org/stable/2195506?seq=1 https://doi.org/10.2307/2195506

Koterski, J. W. (2004). Boethius and the Theological Origins of the Concept of Person. American Catholic Philosophical Quarterly, 78, 203-224. https://doi.org/10.5840/acpq200478212

Lacewing, M. (2017). Philosophy for AS and A Level: Epistemology and Moral Philosophy (1st ed.). London: Routledge. https://www.routledge.com/Philosophy-for-AS-and-A-Level-Epistemology-and-Moral -Philosophy/Lacewing/p/book/9781138690394 https://doi.org/10.4324/9781315171869

LaGrandeur, K. (2014). Ancient Definitions of Personhood and Difficult Social Precedents: The Homunculus, the Golem, and Aristotle. Journal of Evolution and Technology, 24, 20-26. https://jetpress.org/v24.3/LaGrandeur.htm

LaGrandeur, K. (2017). Androids and Intelligent Networks in Early Modern Literature and Culture. Abingdon-on-Thames: Routledge.

https://www.routledge.com/Androids-and-Intelligent-Networks-in-Early-Modern-Lite rature-and-Culture/LaGrandeur/p/book/9781138743342

LE News (2016). Swiss Fact: Switzerland First Country to Consider Dignity of Animals in Constitution. LE News, 5 October 2016.

https://lenews.ch/2016/10/05/swiss-facts-animal-dignity/

Lizza, J. P. (Ed.) (2009). Defining the Beginning and End of Life: Readings on Personal Identity and Bioethics. Johns Hopkins University Press.

Lloyd, S. A., \& Sreedhar, S. (2002). Hobbes's Moral and Political Philosophy. In Stanford Encyclopedia of Philosophy. https://plato.stanford.edu/entries/hobbes-moral/

Locke, J. (2004). An Essay Concerning Humane Understanding. Volume I. MDCXC, Based on the 2nd Edition, Books I. and II. (of 4). http://www.gutenberg.org/cache/epub/10615/pg10615.html

Manner, G. (1952). The Object Theory of the Individual in International Law. The American Journal of International Law, 46, 428-449. https://doi.org/10.2307/2194499

Mason, M. (2012). Environmental Democracy: A Contextual Approach (p. 24). London: Routledge. https://doi.org/10.4324/9781849773836

Mccartney, J. J. (2002). Embryonic Stem Cell Research and Respect for Human Life: Philosophical and Legal Reflections. Albany Law Review, 65, 597-624.

https://www.researchgate.net/publication/11371650_Embryonic_stem_cell_research_a nd_respect_for_human_life_philosophical_and_legal_reflections

McHugh, J. T. (1992). What Is the Difference between a "Person" and a "Human Being" within the Law. The Review of Politics, 54, 445-461.

https://www.jstor.org/stable/1407800?seq=1

https://doi.org/10.1017/S0034670500018258

Miller, R. L., \& Cross, F. B. (2012). Business Law, Alternate Edition: Text and Summarized Cases (p. 79). Cengage Learning.

Morell, V. (2014). Lori Marino: Leader of a Revolution in How We Perceive Animals. National Geographic Innovator's Project. 
https://www.nationalgeographic.com/news/innovators/2014/05/140528-lori-marino-do lphins-animals-personhood-blackfish-taiji-science-world/

Morris, C. (1997). Technology and the Legal Discourse of Fetal Autonomy. UCLA Women's Law Journal, 8, 48-97. https://escholarship.org/uc/item/9wh540rn

Newman, J. (2011). Green Ethics and Philosophy: An A-to-Z Guide (p. 133). Thousand Oaks, CA: SAGE. https://doi.org/10.4135/9781412974608

Ohlin, J. D. (2005). Is the Concept of the Person Necessary for Human Rights? Cornell Law Faculty Publications 434. https://scholarship.law.cornell.edu/facpub/434/

Orebech, P., Bosselman, F., Bjarup, J., Callies, D., Chanock, M., \& Petersen, H. (2005). The Role of Customary Law in Sustainable Development. Cambridge: Cambridge University Press. https://doi.org/10.1017/CBO9780511550621

Ortolani, G. (2018). Citizen Ape: The Fight for Personhood for Humans” Closest Relatives. Mongabay.

https://news.mongabay.com/2018/10/citizen-ape-the-fight-for-personhood-for-human s-closest-relatives

Papazian, S. C. (2016). On the Etymology of Man. Cradle of Civilization. 20 November 2016. https://aratta.wordpress.com/2016/11/20/on-the-etymology-of-man/

Phillipson, C. (1912). Samuel Pufendorf. Journal of the Society of Comparative Legislation, 12, 233-265. https://www.jstor.org/stable/752451?seq=1

Pontzer, H. (2012). Overview of Hominin Evolution. Nature Education Knowledge, 3, 8. https://www.nature.com/scitable/knowledge/library/overview-of-hominin-evolution-8 9010983/

Press Trust of India (2018). Animals Are "Legal Persons", All Citizens Their Parents, Orders Uttarakhand HC. India Today.

https://www.indiatoday.in/india/story/animals-are-legal-persons-all-citizens-their-pare nts-orders-uttarakhand-hc-1277559-2018-07-04

Project R\&R (2005). Austria Bans Experiments on Great Apes. https://cordis.europa.eu/article/id/23797-austria-moves-towards-ban-on-ape-experime nts

Riukas, S. (1998). Persons and Personal Identity: Hume's Ontology of Personhood.

Romanis, E. C. (2019). Challenging the "Born Alive" Threshold: Fetal Surgery, Artificial Wombs, and the English Approach to Legal Personhood. Medical Law Review, 28, 93-123. https://doi.org/10.1093/medlaw/fwz014

Rose, C. V. (1998). The "New" Law and Development Movement in the Post-Cold War Era: A Vietnam Case Study. Law \& Society Review, 32, 93-140. https://doi.org/10.2307/827750

Roth, J. G. (2019). Locke on Personal Identity. In Stanford Encyclopedia of Philosophy Archive. https://plato.stanford.edu/archives/spr2020/entries/locke-personal-identity/

Sattar, M. P. (2020a). Dynamics of International Human Rights Law and Fundamental Rights in Bangladesh Constitution (pp. 96-97). Dhaka: IUB.

Sattar, M. P. (2020b). Non-International Armed Conflict in a New Era of Humanitarian Law. New York: SAGE Advance. https://doi.org/10.31124/advance.13382975

Sattar, M. P., Khan, M. Z., \& Reza, A. (2021). Unborn Fetus or Human Unborn: Paradigms of Legal Homogeneity. The Business Standard.

https://tbsnews.net/thoughts/unborn-fetus-or-human-unborn-paradigms-legal-homogeneit $\mathrm{y}$-184282?fbclid=IwAR3CO3C40Xc0EEbO2MrAYqpMcvmCA72aXjYR4b8QK2_5zZoClex 6lp38qV4\#.X_2nhxKxx_J.whatsapp

Sirota, D. (2004). Debunking “Centrism”. The Nation. 
https://www.thenation.com/article/archive/debunking-centrism/

Sivanada, S. S. (1997). All about Hinduism (6th ed.). India: Divine Life Society Publications. https://www.dlshq.org/download/hinduismbk.htm

Spiermann, O. (2007). Twentieth Century Internationalism in Law. European Journal of International Law, 18, 785-814. https://doi.org/10.1093/ejil/chm045

Stanford Encyclopedia of Philosophy (2019). Human Rights. https://plato.stanford.edu/entries/rights-human/

Stumpf, C. (2006). The Grotian Theology of International Law: Hugo Grotius and the Moral Foundations of International Relations (p. 66). Berlin: Walter de Gruyter.

Taylor, C. S. (2012). The Concept of a Person (pp. 97-114). Cambridge: Cambridge University Press.

Thomas, V. (2019). Attributing Legal Personality to Nature as an Effective Means for Protection. https://www.howtoregulate.org/legal-personality-nature

Vatican (1983). Code of Canon Law.

http://www.vatican.va/archive/cod-iuris-canonici/eng/documents/cic_lib1-cann96-123 en.html

Vatican (1987). Instruction on Respect for Human Life in Its Origin and on the Dignity of Procreation Replies to Certain Questions of the Day (Doctrine of Faith).

https://www.vatican.va/roman_curia/congregations/cfaith/documents/rc_con_cfaith_d oc_19870222_respect-for-human-life_en.html

Von der Pfordten, D. (2009). On the Dignity of Man in Kant. Philosophy, 84, 371-391. http://www.jstor.org/stable/20533206 https://doi.org/10.1017/S0031819109000370

Walbridge, J. (2017). Chap. 35. Selfhood/Personhood in Islamic Philosophy. In E. Eliot Deutsch, \& R. Bontekoe (Eds.), A Companion to World Philosophies (pp. 472-483). Hoboken, NJ: Blackwell Publishing Ltd.. https://doi.org/10.1002/9781405164566.ch35

Walsh, A. (2017). Saudi Arabia Grants Citizenship to Robot Sophia. DW. https://www.dw.com/en/saudi-arabia-grants-citizenship-to-robot-sophia/a-41150856

White, F. J. (2013). Personhood: An Essential Characteristic of the Human Species. The Linacre Quarterly, 80, 74-97. https://doi.org/10.1179/0024363912Z.00000000010

White, T. (2012) Is a Dolphin a Nonhuman Person? LITT. https://mcsphilsoc.wordpress.com/2012/12/07/is-a-dolphin-a-nonhuman-person-by-p rofessor-thomas-white/

Williamson, C. (2013). India Announces Dolphinarium Ban. WDC. https://uk.whales.org/2013/05/20/india-announces-dolphinarium-ban/

Yuhas, A. (2015). Chimpanzees Granted Petition to Hear "Legal Persons" Status in Court. The Guardian.

https://www.theguardian.com/world/2015/apr/21/chimpanzees-granted-legal-personsstatus-unlawful-imprisonment 